\title{
MI 1,6-14: \\ a crítica profética ao culto do Segundo Templo e sua justificativa sob o aspecto teológico
}

\author{
Orientadora: Maria de Lourdes Corrêa Lima \\ Mestrando: Fabio da Silveira Siqueira \\ Área de Concentração: Teologia Bíblica
}

Linha de Pesquisa: Análise e Interpretação de Textos do Antigo e Novo Testamento

O texto de Ml 1,6-14 é uma crítica profética ao culto do segundo Templo. O profeta apresenta sua crítica aos sacerdotes que oferecem animais impróprios para YHWH e também a justificativa da mesma crítica, apresentada nos vv. 11 e 14d-f. A presente dissertação visa verificar detalhadamente o sentido da crítica profética e, particularmente, deter-se sobre o sentido de Ml 1,11, uma vez que a interpretação deste versículo é causa de grande dissenso entre os estudiosos. É objetivo, ainda, da presente dissertação, deter-se sob o aspecto teológico da justificativa da crítica profética ao culto encontrada em Ml 1,11 e 14d-f. Para atingir tal objetivo a pesquisa começa com a tradução do texto, sua delimitação e colocação no conjunto do livro de Malaquias. Depois aborda-se a organização do texto, sua unidade, datação e gênero literário. Num terceiro momento é feito o comentário aos vv. 6-10.12-14a-c. Os vv. 11 e 14d-f são comentados num capítulo à parte, onde se dedica uma maior atenção ao v. 11, estabelecendo-se, em primeiro lugar, o status quaestionis da sua interpretação, desde o judaísmo tardio até o momento atual. No último capítulo se aborda o pano de fundo teológico subjacente à crítica profética e a relação de Ml 1,6-14 com Nm 6,23-27. Este estudo chega à conclusão de que a crítica profética de Ml 1,6-14 revela pontos de contato com $\mathrm{Nm} \mathrm{6,23-27,} \mathrm{sendo} \mathrm{uma} \mathrm{espécie} \mathrm{de} \mathrm{anti-bênção} \mathrm{com}$ a qual os sacerdotes e o povo (cf. M 1,14) são condenados por não prestarem a YHWH o culto na sua forma devida e com a adequada disposição interior. Mostra também que, para entender o sentido real do v. 11 é necessário lê-lo em conjunto com o v. 14d-f, levando em conta a teologia do "nome" de YHWH e a imagem de YHWH como "rei" que estão subjacentes à perícope como um todo.

Palavras-chave: Teologia Bíblica; Segundo Templo; Profetismo; Livro de Malaquias. 